\title{
The second-round effects of carbon taxes on power project finance
}

\author{
Paul Simshauser and Tim Nelson* \\ Level 22, 101 Miller Street \\ North Sydney, NSW, 2060. \\ April 2011
}

\begin{abstract}
The most problematic area of any carbon policy debate is the treatment of incumbent $\mathrm{CO}_{2}$ intensive coal-fired electricity generators. Policy applied to the electricity sector is rarely well guided by macroeconomic theory and modeling alone, especially in the case of carbon where the impacts are concentrated, involve a small number of firms and an essential service. Our Australian case study finds that if zero compensation results in the financial distress of project financed coal generators, finance costs for all plant rises, including new gas and renewables, leading to unnecessary increases in electricity prices. Accordingly, an unambiguous case for providing structural adjustment assistance to coal generators exists on the grounds of economic efficiency.
\end{abstract}

Keywords: Carbon Tax, Project Finance, Electricity Prices. JEL Codes: D61, L94, L11 and Q40.

\section{Introduction}

One of the most intriguing issues associated with the Global Financial Crisis was the complete failure of the roughly 13,000 economists in the US to predict it (Samuelson, 2009). At the time, most economists were focused on inflationary pressures and an overheating global economy. The crisis originated in the capital markets, but financial economics occupies, at best, a peripheral position in mainstream economics. Financial economics also occupies, at best, a peripheral position in any carbon policy debate. But as this article subsequently reveals, it must be elevated to centre-stage for similar reasons.

Pricing carbon is designed to hasten the exit of coal plant from power systems. Despite the pointed and business-disruptive nature of the policy intent, debate on carbon pricing and coalfired generation in Australia does not centre on whether such a framework should be implemented. All sides of the debate, including coal-fired asset owners, agree it should. The issue comes down to how plant might exit; with or without compensation. At one extreme is the asbestos argument; that incumbent generators should not receive assistance. At the other is the expropriation argument; that full compensation for asset loss is warranted. Policy is rarely well guided by emotive arguments. Nor will carbon policy applied to the electricity sector be well guided by macroeconomic theories and modeling alone given that wealth impacts are concentrated, non-trivial, involve a small number of firms and an essential service. Financial economics, in this instance, has a central role to play in macroeconomic policy formulation.

To illustrate why, we focus on Australia's 7,000 MW brown coal power station fleet. Brown coal generators have above grid-average $\mathrm{CO}_{2}$ intensity coefficients and are therefore more likely to experience financial distress in the short run. Additionally, they are privately owned and mostly financed by non-recourse project debt. ${ }^{1}$ Modeling results later in this article reveal adverse second-round effects for power project finance under a "zero compensation scenario" with brown

\footnotetext{
* Paul Simshauser is Chief Economist at AGL Energy Ltd and Professor of Finance at Griffith University. Tim Nelson is Head of Economic Policy and an Adjunct Research Fellow at the University of New England.

${ }^{11}$ The case for structural adjustment assistance to the 22,000MW black coal fleet is weaker; more than $70 \%$ of black coal plants are owned by State Governments and financial distress is therefore unlikely to produce material efficiency losses in capital markets. Also, black coal generators have grid-average carbon intensity coefficients and are therefore less likely to experience acute financial distress in the short run. To be sure however, over the long run, the same fate ultimately awaits black coal plant, albeit on a slower-burn trajectory.
} 
coal plant financial distress. We therefore find an unambiguous case for providing structural adjustment assistance on the grounds of economic efficiency.

This article is structured as follows; Section 2 reviews the theory of structural adjustment. Section 3 analyses the impact of carbon prices on generator cost structures. Section 4 analyses capital flows and reviews our survey results on project finance in Australia's National Electricity Market. Section 5 presents our project finance modeling results. In Section 6, the entry cost estimates from Section 5 are translated to our dynamic partial equilibrium model to produce power system economic efficiency losses. Policy recommendations follow.

\section{On the theory of structural adjustment assistance}

In current carbon policy debates, advisors and policymakers with a macroeconomic bias seem to favour a cut-and-run approach, underscored by limited or even zero compensation to incumbent coal-fired generators. This reflects a Washington Consensus approach to reform. ${ }^{2}$ This approach observes that carbon pricing has been well telegraphed and asset owners have had years to prepare, and government should not provide taxpayer funded protection to sunset industries or those who produce negative externalities (e.g. asbestos, tobacco, coal-fired power). Where assistance has historically been provided to generators as a transitional measure such as in the EU ETS, supranormal profits were extracted from an overgenerous free permit allocation. Moreover, from a transitional perspective, neo-classical economic theory and modeling has long been comfortable with the notion that short run capital losses reflect the workings of an efficient market and new owners will acquire distressed assets at more appropriate (post-policy) values without any disruption to supply. History abounds with examples; producers forecast dire consequences when Australia's 10\% Goods and Services Tax (GST) was introduced in 2000. Yet no assistance was offered, and the economy adjusted without incident.

Simshauser (2008) noted that economists must commence the analysis of any major reform with the notion that there is no basis for compensation mechanisms to offset direct or indirect losses associated with a policy that is designed to drive economic efficiency. If it were not for this default approach, governments would be unable to function properly as Pasour (1973), Neary (1982), Johnson (1994), Argy (1999) and many others have noted. It is simply impractical to assess economy-wide losses for all policy changes. Besides which, efficiency gains and losses from reform programs tend to even-out over the long run, with society considerably better off in the end.

Moreover, in many cases the delivery of assistance would impair the economic efficiency that a policy measure is trying to drive in the first place. For example, providing production subsidies (rather than structural adjustment assistance) to coal generators whilst introducing a carbon tax would clearly be a destructive log-rolling policy; ${ }^{3}$ the tax is designed to drive coal generators out of business while production subsidies are designed to protect firms and keep them in business. Furthermore, if every change included adjustment programs, the outcome would more than likely lead to moral hazard, whereby investors believe their future actions are protected against policy change through government intervention. Accordingly, the notion of zero compensation may have solid foundations in theory and practice.

\footnotetext{
${ }^{2}$ The term "Washington Consensus" relates to a consensus reached in the 1980s between the US Treasury, World Bank and the International Monetary Fund. At its core is a deep belief in economic reform and the efficiency of markets, in particular, fiscal policy discipline, trade liberalisation, deregulation of capital markets, privatisation of state enterprises, industry deregulation, establishment of property rights and so on. The Washington Consensus, and the virtual blind faith in the efficiency of markets, was largely abandoned in late-2010 following the effects of the global financial and economic crisis (for example, see Macquarie Securities, 2011). In contrast, a Keynesian approach for example favours markets and competition, but accepts the potential for market failure and the necessary role of government in subsequent economic stabilization.

${ }^{3}$ Log-rolling policies are implemented in conjunction with reform policies to dampen the sharpest effects of a reform, in the event making it more politically feasible. An example of carbon log-rolling policy would be compensation to low income households. 
But for markets to adequately solve for large shocks, all the conditions and assumptions of economic theory and models must be present. Stiglitz (2002) observed that one of the great achievements of modern economics has been to demonstrate how rarely this occurs in practice. To that end, there are clear conditions in economic theory and in practice where structural adjustment assistance is desirable on the grounds of economic efficiency (Argy, 1999). If a given reform is likely to lead to a material misallocation of resources, then there is a case for further analysis and intervention. In most western economies, industries tend to qualify for structural adjustment assistance where reform shocks are (a) large, (b) policy driven events, (c) breach long standing expectations and (d) are likely to produce highly uneven or magnified losses in discrete industrial segments (Argy, 1999).

Given the theory on structural adjustment, policymakers with an energy or financial economics bias tend to baulk at a Washington Consensus approach to the application of carbon policy. The 2008 global financial crisis aptly demonstrated that great care must be taken when guiding policy exclusively via macroeconomic theory and modeling. Stiglitz (2002) provides a long list of reform policy failures which can be traced back to an overreliance on macroeconomic constructs. Requisite caution is necessarily heightened when wealth impacts of a policy reform are concentrated, large, involve a small number of firms with large productive capacity, and the reform target is an essential service like electricity supply. This latter point is critical and distinguishes coal generation from other products with negative externalities such as asbestos, where substitutes are immediately available at equivalent cost.

In Computable General Equilibrium (CGE) Modeling, a staple input to macroeconomic decision making, firms and production processes within an industry segment are essentially passive variables. The equivalent of a $2000 \mathrm{MW}$ base load power station could theoretically produce $1 \mathrm{MW}$ in a year in a CGE Model, despite being technically and economically intractable in the real world. ${ }^{4} \mathrm{On}$ the other hand, the primary tools used in financial and microeconomic analysis, dynamic multi-period partial equilibrium models and financial models at the project level, by necessity deal with a level of detail entirely unfamiliar to CGE Modeling, albeit with an intensely narrow focus. Electricity sector models typically involve half-hourly resolution of resource allocation across multiple years and crucially, capture plant-specific constraints, transmission congestion and regional demand, thus attempting to mimic the rich dynamics of high impact events on demand, production, price, and in this case, NEM emissions, energy security and systemic security.

Coal power plants tend to be very large relative to other plant types and supply a dominant component of aggregate demand. As Table 1 later illustrates, about $81 \%$ of Australia's power comes from just 31 coal-fired generation plants. And so electricity sector modeling tends to reinforce the view that systemic or physical disruption events arising from policy-induced financial distress of coal plants is more than a theoretical possibility. Conversely, a macroeconomist would argue that the withdrawal of supply will be divisible, will raise price, and that the market will quickly equilibrate at a new and higher level. A Washington Consensus approach to such matters would be that new owners would acquire distressed brown coal assets, thus averting collapse and in the process reset the cost-base of the plant in the post-policy environment. Perhaps.

But in this instance it is obvious that unique conditions exist; carbon policy is designed to drive coal generators out of business. And so financial economic analysis will reveal that the field of buyers for a terminal coal power station with negative operating margins and looming, non-trivial closure costs associated with asbestos removal and mine rehabilitation must surely be zero. Additionally, coal plant cannot be operated economically on an intermittent basis when it has

${ }^{4}$ Of course, a macroeconomic model would not incorporate any specific plant level details. But the point is that CGE models can produce outcomes which, given the existing plant stock, are technically intractable due to technical limitations of power systems. 
been purposefully designed, engineered, manned and more importantly, financed for base load duties.

A systemic shock in the NEM is plausible if a large $\mathrm{CO}_{2}$ intensive coal facility not provided with structural adjustment assistance collapsed unexpectedly under the weight of a carbon price. The reason for this is straightforward enough; forward electricity hedge contracts form part of the unsecured market for derivative instruments, and Administrators of moribund plant have broad powers to cancel committed hedge contracts. This is not contentious. Administrators would only cancel forward hedge contracts at the very point in time that they are most needed by demandside participants; that is, when they are deeply out-of-the-money. Further contagion in the NEM could result, causing the financial distress of other energy businesses that were otherwise stable. A more sobering thought is that given the nature of deregulated wholesale energy markets and the presence of retail price regulation, no energy retailer in the NEM is too big to fail on financial grounds under shock conditions, especially with a market price cap that is 200 times average price. $^{5}$

This is not without precedent. Energy and financial economists therefore harbor reservations about the prospect of market stability under sustained structural shocks to power systems, not because they fear the wholesale market will not respond correctly, but because it will respond correctly. Given the regulation of retail electricity tariffs, there is an imperfect transmission of price movements from wholesale to retail markets. ${ }^{6}$ This issue is material. Price-cap regulation dictates electricity tariff caps to more than $72 \%$ of the 8.9 million households in the NEM. And the deregulated tariffs of the remaining $28 \%$ of households are constrained to six-monthly movements. The last time a deregulated wholesale energy market snapped where retail prices were regulated, two of the largest Investor-Owned Utilities in the US were bankrupt within six months of the initial shock event (Joskow, 2001; Bushnell, 2004).

Competitive energy markets were designed to drive productive, allocative, and dynamic efficiency. The NEM has been enormously successful at driving all three (Simshauser, 2005). But the dynamic efficiency objective function was largely one-directional; providing appropriate signals for new entry and consequences for excess entry. Energy markets are not typically designed, or well equipped, to deal with policy-induced lumpy plant exit. And nor should they be since such events must be rare in practice. But if plant exit is induced by tangential carbon policy, and exit is not carefully orchestrated, systemic or physical disruption is plausible.

But in our view, these short-run impacts pale into insignificance by comparison to the long run consequences arising from the capital markets, which is the prime focus of this article. Power generation is the world's most capital-intensive industrial activity. In Australia, this activity occurs in an economy with a severe structural reliance on foreign capital (Simshauser, 2010). Consequently, policy-induced disruption to power generation investments could have adverse impacts on capital market participation rates, costs of capital, and capital inflows to the industry. In the balance of this article, we quantify efficiency losses in capital markets relating to remaining and future generating equipment under conditions of a Washington Consensus, free market approach involving zero compensation to brown coal generators.

\section{The impact of carbon prices on power station cost structures}

Australia's aggregate generating capacity is $53,216 \mathrm{MW}$ as Table 1 notes. The fleet produces 229,756 GWh and emits about 200 million tonnes per annum (Mtpa) of carbon dioxide equivalent

${ }^{5}$ Wholesale prices average about $\$ 50 / \mathrm{MWh}$. The administered price cap in the NEM spot market is currently $\$ 12,500 / \mathrm{MWh}$.

${ }^{6}$ Deregulated wholesale energy markets like the NEM will perform to all economists' expectations in that prices can and will rise sharply when structural shocks occur. But the NEM has demonstrated on several occasions that regulated retail prices are simply incapable of keeping pace with seismic shifts by comparison to the $1 / 2$ hourly spot market clearing mechanism and the instantly responding forward contract market. Two niche retailers and one government owned retailer became technically insolvent over such mismatches in the NEM since 1998. 
(CO2e). Table 1 distinguishes between brown coal, black coal, gas and renewables (i.e. hydro and wind). There are 155 sites of which eight will be intensely affected in the short-run from carbon pricing. There is 7,335 MW (14.2\%) of brown coal plant which produces a quarter of Australia's aggregate electricity output with emissions intensities up to $1.55 \mathrm{t} / \mathrm{MWh}$. The average age of the power station fleet is 24.8 years, with brown coal averaging 32.2 years. Our rule-ofthumb valuation estimate ${ }^{7}$ of the brown coal fleet is $\$ 7.8$ billion. Importantly, existing coal-fired plants in the NEM are thought to have significant remaining technical useful lives. Outhred (2011) estimated this to be in excess of 20 years, a number few would disagree with.

Table 1: Australian power station fleet in 2010 (grid-connected, excluding embedded plant)

\begin{tabular}{lcccccccccc}
\hline Technology & $\begin{array}{c}\text { Sites } \\
(\mathrm{No} .)\end{array}$ & $\begin{array}{c}\text { Capacity } \\
(\mathrm{MW})\end{array}$ & $\begin{array}{c}\text { Share } \\
(\%)\end{array}$ & $\begin{array}{c}\text { Output } \\
(\mathrm{GWh})\end{array}$ & $\begin{array}{c}\text { Share } \\
(\%)\end{array}$ & $\begin{array}{c}\text { CO2 Intensity } \\
(\mathrm{t} / \mathrm{MWh})\end{array}$ & $\begin{array}{c}\text { Replacement } \\
(\mathbf{\$ M})\end{array}$ & $\begin{array}{c}\text { Fleet Value } \\
(\$ \mathrm{M})\end{array}$ & $\begin{array}{c}\text { Fleet Age } \\
(\text { Years })\end{array}$ \\
\hline Brown coal & 8 & 7,335 & 13.8 & 57,063 & 24.8 & $1.10-1.55$ & 22,005 & 7,829 & 32.2 \\
Black coal & 23 & 22,280 & 41.9 & 129,401 & 56.3 & $0.80-0.97$ & 49,016 & 24,128 & 25.4 \\
Gas & 74 & 15,285 & 28.7 & 28,322 & 12.3 & $0.38-0.70$ & 18,342 & 9,872 & 13.9 \\
Hydro \& Wind & 50 & 8,316 & 15.6 & 14,970 & 6.5 & n/a & 24,594 & 13,016 & 36.8 \\
\hline Total & 155 & 53,216 & 100.0 & 229,756 & 100.0 & 0.92 & 113,957 & 54,845 & 24.8 \\
\hline \multicolumn{8}{c}{ Source: esaa (2010), AGL Energy Ltd. } & & &
\end{tabular}

This data highlights that the number of intensely affected sites in the short run is minimal, and the value of those affected is small in the context of the aggregate generation portfolio. The value is also small by comparison to the roughly $\$ 6$ billion 'annual take' in carbon taxes that will accrue from the power sector at $\$ 30 / \mathrm{t}$.

Applying a price to carbon is designed to shift the industry cost structure, and the most adversely affected will be the brown coal fleet due to their especially high $\mathrm{CO}_{2}$ intensity. To determine the degree of asset value loss for a discrete generator, the emission intensity of the plant must be compared to the rate of carbon pass-through in the wholesale market. Where a generator's emission intensity is greater than the rate of the whole-of-market pass-through, it will incur carbon costs that are greater than recoverable through the market. It is in these circumstances that a generator is likely to experience asset value loss through reduced operating margins, lower volumes and a truncated economic life.

In the short-run before significant substitution of capital can occur (i.e. given development lags of 5 years), the rate of carbon pass-through in the wholesale market is likely to reflect the fleet average $\mathrm{CO}_{2}$ intensity of about $0.9 \mathrm{t} / \mathrm{MWh}$ (Nelson et al, 2011). In the long-run (i.e. beyond 5 years), the pass-through rate is likely to decay from the grid average as new lower-intensity generation becomes the marginal generator for non-trivial price-setting periods each year.

The shortening of a generator's economic life is therefore a function of two variables: the spread between its individual emissions intensity and the market intensity (reduced operating margins); and the rate at which the average intensity declines. Policymakers must establish whether they should provide structural adjustment assistance to debt and equity capital investors to deal with reduced operating margins, lower volumes and truncated economic life, and subject to the geographic location of substitution outcomes, displaced workers. The short run objective of any structural adjustment assistance therefore needs to enhance the predictability of capacity exit to avoid disruption events; and as modeling results later in this article reveal, the long run objective should be to short-circuit second-round effects in the capital markets.

From an entry cost perspective, levelised cost modeling in Simshauser (2011) highlighted the comparative effects that carbon pricing would have on new coal plant relative to rival technologies. Note in Figure 1 that the relative carbon tax accruing to brown and black coal plant is materially higher than Combined Cycle Gas Turbine (CCGT) plant. Consequently, on

\footnotetext{
${ }^{7}$ We use a simple new entrant cost multiplier of about $\$ 3000 / \mathrm{kW}$ for brown coal plant, over a 50 -year term.
} 
generalized Long Run Marginal Cost (LRMC) modeling at least, new plant using existing coal technologies is uneconomic.

Figure 1: Generalised LRMC of utilities-scale energy technologies

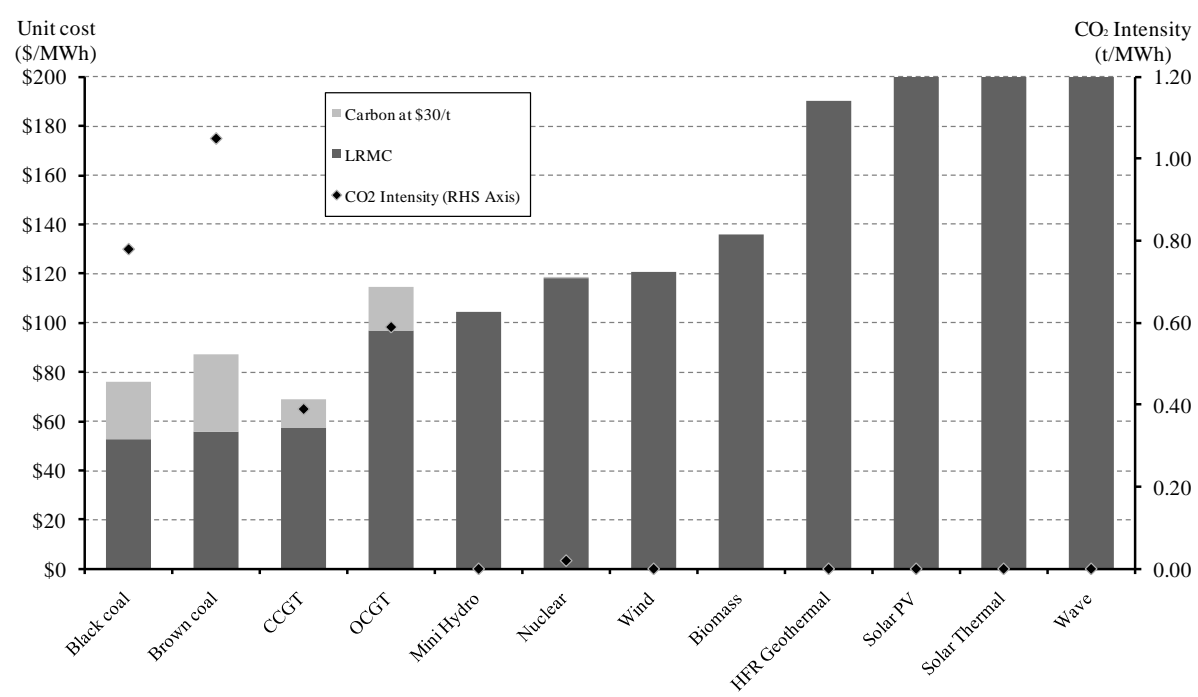

Source: Simshauser (2011)

The analysis in Figure 1 deals with new investment. More important to the carbon debate is the impact on incumbent plant. Figures 2 and 3 illustrate generalized marginal running costs of the NEM's roughly $38,000 \mathrm{MW}$ thermal fleet before, and after, a $\$ 30 / \mathrm{t}$ carbon price. In Figure 2, where carbon prices are excluded, the brown coal fleet sits at the bottom of the aggregate supply function with marginal running costs of about $\$ 5 / \mathrm{MWh}$. In contrast, the marginal running cost of base load gas plant (at $\$ 4.50 / \mathrm{GJ}$ ) is over $\$ 30 / \mathrm{MWh}$.

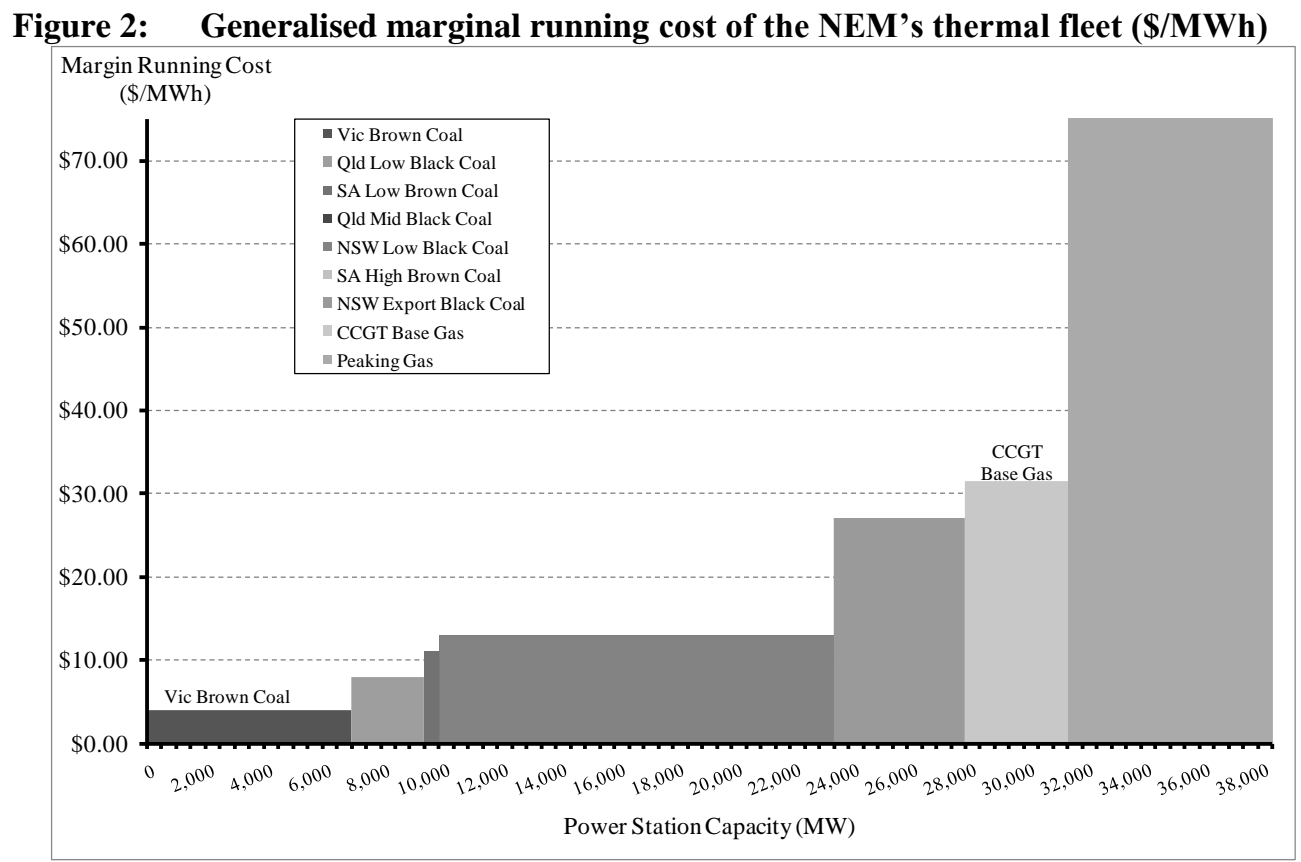

Figure 3 illustrates the change in the plant pecking order or merit order once carbon taxes are introduced. The arrows identify the location of brown coal generators in the newly formed aggregate supply function. Note the CCGT base load plant is creeping up the merit order, 
dislodging brown coal plant and any black coal plant exposed to export coal prices. CCGT's will also become more competitive as the price of carbon rises due to their low carbon coefficient.

Figure 3: Generalised marginal running cost of the NEM's thermal fleet at $\$ 30 / \mathrm{t} \mathrm{CO}_{2}$

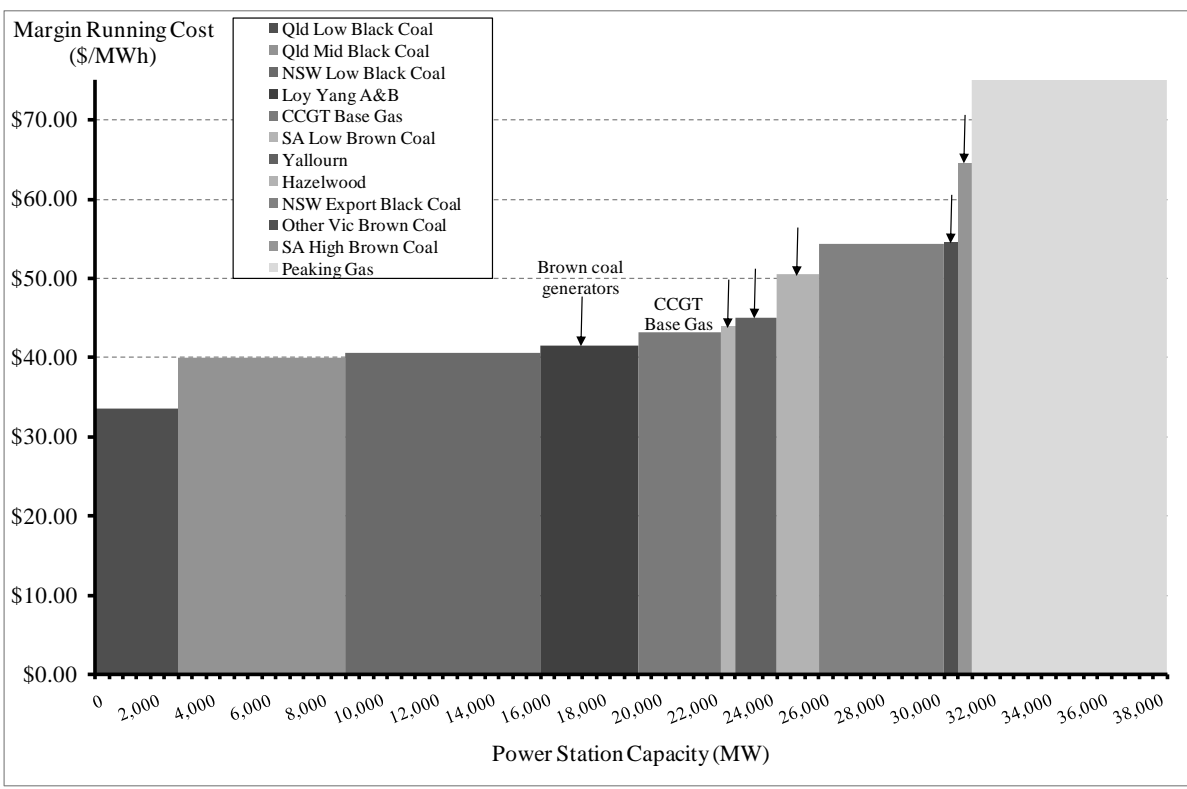

A characteristic evident from Figures 2 and 3 is the relative size of the incidence of a carbon tax. On a production-weighted basis, a $\$ 30 / t$ carbon tax increases the marginal running cost of brown coal plant by 10.2 times. For black coal plant, marginal costs increase by 3.0 times, and 1.4 times for CCGT plant. These marginal running cost multipliers provide some insight into the impact on brown coal plant, and why gas plant has such a material advantage as carbon prices rise. The marginal running cost multipliers also highlight why other tax reforms such as the introduction of the GST should not provide policymakers with comfort under zero compensation. The GST resulted in input costs of goods and services increasing by a multiplier of 1.1 times, a trivial amount. The carbon impact on brown coal plants is 9.1 times greater than the GST. Comparisons of carbon policy with previous broader economic reforms in the context of deciding sunset industry assistance would therefore be misguided at best and dangerous at worst due to the impacts being an order of magnitude different.

Over the past ten years, there have been a number of studies completed by businesses, governments and industry associations on the impacts of carbon pricing on coal-fired power station asset values. Losses for NEM generators have been modeled at $\$ 11.0$ billion by ACIL

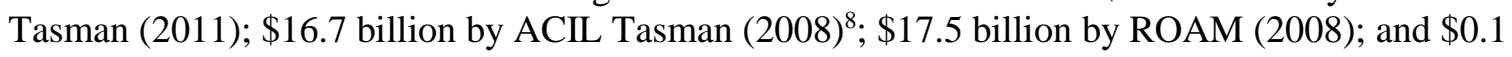
billion by MMA (2008). The privately owned brown coal generators have been forecast to experience losses of $\$ 7.1$ billion, $\$ 7.9$ billion and $\$ 2.3$ billion in the respective 2008 studies. $^{9}$ Differences between studies will invariably be driven by assumptions around market behavior, structure, and the carbon pass-through rate. We are unaware of any modeling literature in Australia that indicates brown coal generators will not experience disruptive losses. Based upon these results, it is not surprising that the structural adjustment assistance proposed for the 2008 Australian ETS legislation (which was defeated in the Senate) involved $\$ 7.3$ billion in nominal terms (DCC, 2009). Asset loss will be material due to declining operating margins, loss of market share and a truncated economic life. None of this is contentious. It underscores the whole point of carbon pricing.

\footnotetext{
${ }^{8}$ The 2008 and 2011 ACIL Tasman results reflect both different input assumptions (one study was commissioned by the Department of Climate Change whereas the other utilises ACIL figures) and different reduction scenarios.

${ }^{9}$ All figures are in \$2007 except the ACIL Tasman (2011) study which is in 2011\$.
} 


\section{Capital flows and project finance survey results}

An important characteristic of the Australian economy is a severe structural reliance on foreign capital for investment purposes. This is due to Australia's low household saving rates, an aboveaverage proportion of capital-intensive industries such as energy, metals manufacturing, utilities and mining, along with a small population of 22.5 million people spread over a large area, which raises requirements for transport and distribution infrastructure (Simshauser, 2010). The outworking of this is best illustrated by net capital flows into the Australian economy, in Figure 4. Note that from 2001-2009, about \$1 trillion of net foreign capital flowed in-bound. Since 2006, foreign capital inflows have financed about $58 \%$ of Australia's new fixed assets. Since the utilities sector is the world's third largest borrower of debt behind governments and banks respectively, capital flows should be of considerable importance to carbon policymakers (Simshauser, 2010).

Figure 4: Net flows of foreign capital to Australia

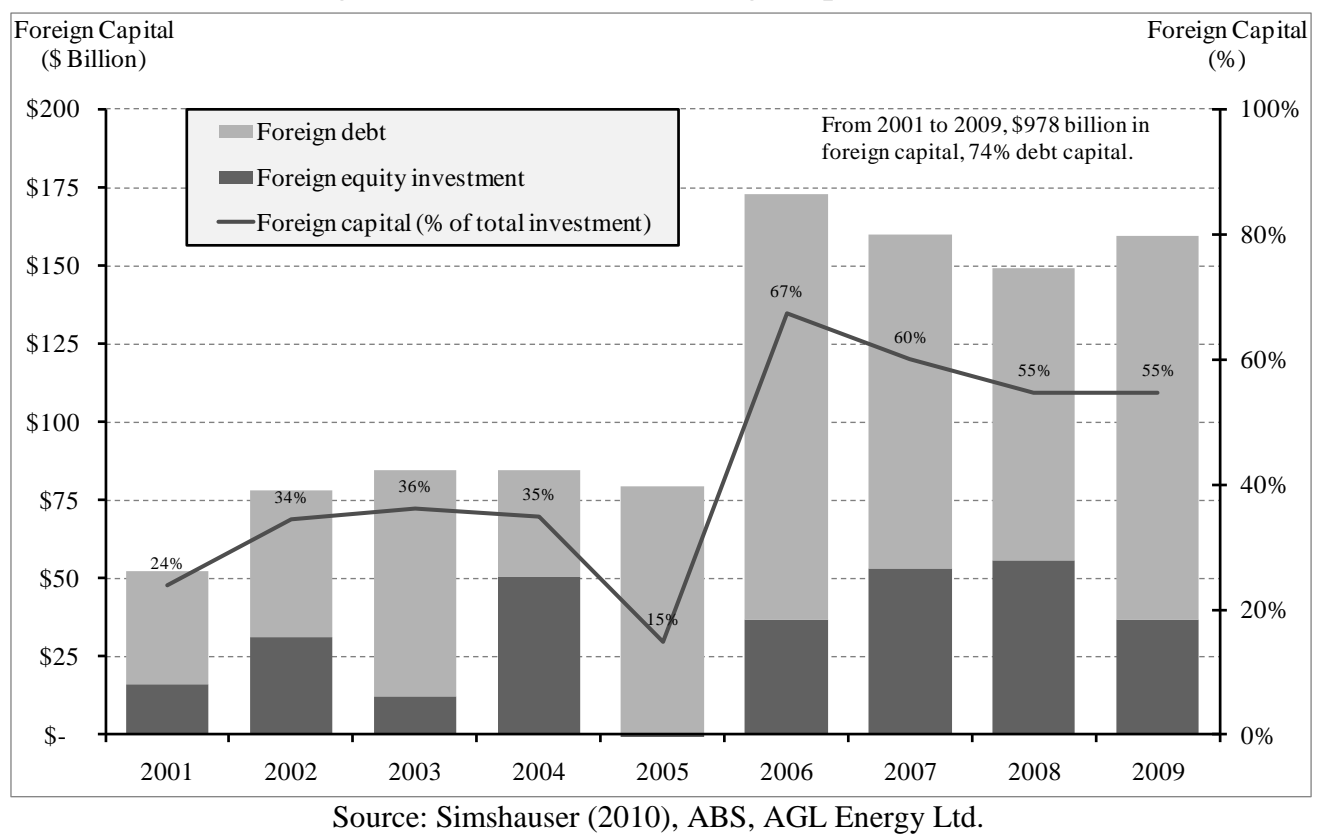

Foreign capital flows provide important background context to the debate on structural adjustment assistance to brown coal generators. If a concentrated portfolio of assets in the capital-intensive power sector becomes systematically distressed as a result of policy change, no matter how novel that policy might be, it is unlikely that financing conditions will remain constant thereafter. Table 3 outlines debt facilities on Australia's four largest brown coal-fired power stations: 
Table 2: Latrobe Valley Syndicated Debt (A\$ million)

\begin{tabular}{|c|c|c|c|c|c|}
\hline Banks & Loy Yang A & Loy Yang B & Hazelwood & Yallourn & Total \\
\hline ANZ & 113 & 123 & 64 & 75 & 375 \\
\hline NAB & 183 & 123 & & 90 & 396 \\
\hline BTMU & 126 & 123 & 47 & 29 & 325 \\
\hline Westpac & 82 & & 45 & 120 & 247 \\
\hline RBS & 162 & & 103 & 120 & 385 \\
\hline BNP Paribas & 81 & 123 & 41 & 71 & 316 \\
\hline SMBC & 126 & 98 & & 36 & 260 \\
\hline CBA & & 221 & & 36 & 257 \\
\hline Societe Generale & 125 & & 64 & & 189 \\
\hline DBJ & 150 & & & & 150 \\
\hline Credit Agricole Indosuez & 90 & & 52 & & 142 \\
\hline West LB & 71 & & 62 & 45 & 178 \\
\hline Mizuho & 126 & & & 30 & 156 \\
\hline BOS International & 70 & & 52 & & 122 \\
\hline China Construction Bank & 108 & & & & 108 \\
\hline Dexia & 70 & & 31 & & 101 \\
\hline STB & 100 & & & & 100 \\
\hline CIBC & & 98 & & & 98 \\
\hline Deutsche Bank & & 98 & & & 98 \\
\hline MUFJ & & 98 & & & 98 \\
\hline United Overseas Bank & 71 & & 22 & & 93 \\
\hline KBC Bank & 81 & & & & 81 \\
\hline UniCredit Group & 70 & & & & 70 \\
\hline Aozora & 50 & & & & 50 \\
\hline Other Foreign Banks (12) & 108 & 0 & 161 & 548 & 817 \\
\hline Total & 2163 & 1105 & 744 & 1200 & 5212 \\
\hline
\end{tabular}

Source: Reuters, AGL Energy Ltd, Macquarie Capital, TRUenergy.

Syndicated debt at the four power stations totals $\$ 5.212$ billion, which is spread across 36 institutions. About 14 banks are currently active in originating debt facilities, with the involvement of others by way of syndication. Importantly, if one or more of the brown coal generators defaults on debt facilities under conditions of zero compensation, capital market perceptions of the regulatory environment within the Australian electricity industry will deteriorate further. ${ }^{10}$ We therefore opted to test the following proposition:

- That the combination of a default on a project debt facility and zero compensation at a brown coal power station would result in a step-change in debt finance costs for all plant, including future gas and renewable plant.

To test our proposition, we issued a survey to Australia's top 30 project finance bankers who represent the 14 active foreign and domestic banks in originating power project financings. The bank response rate to the 22 question survey was $65 \%$. The survey had two primary sections, and purposes. The first sought bankers' views on historic and current power project financings in Australia. Questions focused on spreads for term facilities, maximum tenors and gearing levels achievable, the number of Mandated Lead Arranging (MLA) banks required to close a $\$ 500$ million facility for a gas-fired power station, the number of banks likely to be included in any syndication, and the number of active banks in the broader market for a power Project Finance (PF). We selected three points in time; 2006 to represent the period before the global financial crisis, 2008 as representative of 'during the crisis', and 2011 given 'carbon policy uncertainty'. Summary results from the first segment of the survey are contained in Table 3. Observed spreads

\footnotetext{
${ }^{10}$ Substantive risk premia are already being applied to existing coal plant. Hazelwood attempted to refinance a roughly $\$ 400 \mathrm{~m}$ term facility that was nearing the end of its 10-year tenor in 2010. It is well understood that in the process, the syndicate opened up not only the existing facility, but another established term facility despite the fact that it was not maturing. Fully 400bps was applied to both structures with a tenor of just $2 \frac{1}{2}$ years and a cash-sweeping mechanism. On an incremental basis, the $\$ 400 \mathrm{~m}$ facility had an effective margin of 700bps.
} 
for BBB credit-rated 3-year Australian corporate bond issues are also included to provide a benchmark to compare the movement in PF spreads.

Table 3: Survey results on perceptions of PF facilities in 2006, 2008 and 2011

\begin{tabular}{|c|c|c|c|}
\hline & 2006 & 2008 & 2011 \\
\hline PF Spreads & $100-120 \mathrm{bps}$ & 400-450bps & 350-400bps \\
\hline Spread Movement & Stable & Up $3.8 \times$ & Down $11 \%$ \\
\hline Max tenor & 12 years & 3 years & 7 years \\
\hline Max gearing & $65 \%+$ & Approx $55 \%$ & Approx $60 \%$ \\
\hline MLA Banks & 3 or less & $7-8$ banks & 7-8 banks \\
\hline Syndication Banks & 3 or less & Club deal & 4-8 banks \\
\hline Active Banks & 29 & 11 & 14 \\
\hline Spread on BBB Bonds & $85 \mathrm{bps}$ & $360 \mathrm{bps}$ & $240 \mathrm{bps}$ \\
\hline Spread Movement & Stable & Up $4.2 \times$ & Down $33 \%$ \\
\hline
\end{tabular}

Conditions to minimize the cost of power projects were ideal in 2006, with spreads at 100-120bps over swap, 12 year tenors (which reduces refinancing risk, thereby facilitating) gearing levels of $65 \%+$, and low transaction costs with only 3 MLA banks required to close facilities. If 2006 was the low water mark, 2008 must surely represent the high water mark. Spreads increased nearly four-fold as global liquidity evaporated in line with the global financial crisis. Figure 5 illustrates the rapid deceleration of global liquidity in the market for syndicated debt; it notes debt issuance across all industries during 2007 was fully US $\$ 3.2$ trillion, but shrunk three-fold to just US\$1.05 trillion after the Lehman collapse in 2008 (Simshauser, 2010).

Figure 5: Global market for syndicated debt

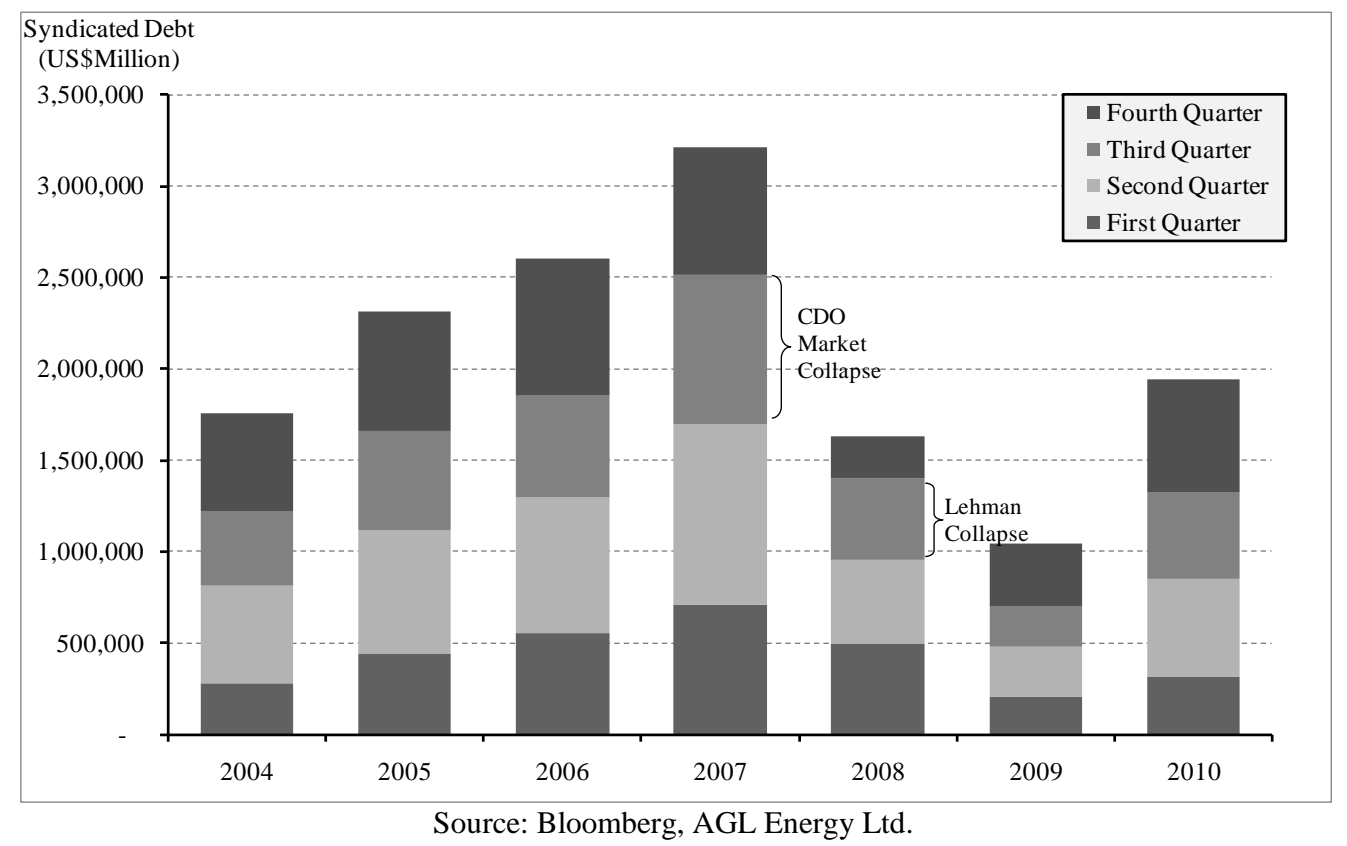

In the case of Australian power PF, note from Table 3 that tenors reduced from 12 years to just 3 years in 2008, while the number of MLA's required to close a $\$ 500 \mathrm{~m}$ power PF deal increased substantially from 3 to 7-8 banks. None would take syndication risk; all transactions were club deals (i.e. debt provided on a 'take and hold' basis). Finally, the number of active banks has reduced considerably although a small number have returned since 2008.

The most striking result in Table 3 is the PF spread movement for power projects by comparison to corporate bonds. There was a parallel run-up in bond and PF spreads between 2006 and 2008 
with a multiplier of approximately 4 times, but a sharp differential in the retreat to 2011 . Table 3 notes that bond spreads have fallen from 360bps to 240bps (33\%) since 2008 whereas power PF spreads have reduced by just $11 \%$.

We tested whether Australian power PF data is out of step with global trends by analysing a comprehensive listing of global power project financings from their recorded inception in 1981 through to the time of writing in Q1 2011. This data represents 3140 individual transaction facilities across 101 countries, with a total facility value of A $\$ 2.76$ trillion (in 2011\$). Summary results are provided in Table 4.

Table 4: Aggregate global power PF deals from 1981 to Q1 2011

\begin{tabular}{lccccc}
\hline & $\begin{array}{c}\text { Number of Power } \\
\text { Station PF's }\end{array}$ & $\begin{array}{c}\text { Average PF } \\
\text { Facility Tenor } \\
(\text { (Years) }\end{array}$ & $\begin{array}{c}\text { Average PF } \\
\text { Facility Spread }\end{array}$ & $\begin{array}{c}\text { Average PF Facility } \\
\text { Size (2011\$) }\end{array}$ & $\begin{array}{c}\text { Global Syndicated } \\
\text { Debt (2011\$) }\end{array}$ \\
\hline $1981-2007$ & 2,028 & 11.5 & 143 & 938.0 & (AUD Million) \\
(AUD Million)
\end{tabular}

Source: Reuters, AGL Energy Ltd.

Intriguingly, whereas Australian power PF have shortened in tenor from 12 years in 2006 to seven years in 2011, and margins remain elevated at 350-400bps as noted in Table 3, global PF data in Table 4 presents a very different picture. Of the more than 1100 transactions completed globally during $2008-2011$, average tenors actually lengthened from 11.5 years to 13.2 years and margins, while elevated, have averaged 236bps. The explanation for this is straightforward enough; the rest of the world does not have the same uncertainty over carbon policy that Australia does. ${ }^{11}$ One of Australia's most respected power project bankers recently noted that "the investment community correctly attaches a risk premium for the added uncertainty, which effectively increases the cost of capital to the industry" (Satkunasingam, 2011, p. 1). Had Australia's proposed ETS been legislated back in 2009 when first brought before the Senate, our view is that PF tenors and margins (in Australia) would have been more likely to gravitate towards global average trends and the trend in corporate bonds, that is, spreads below 300bps and tenors of $10+$ years.

This leads us to the second segment of our survey, given uncertainty over carbon policy. Here, bankers' views were sought on the potential impact of the financial distress of an existing coal asset as a direct result of carbon pricing, but crucially, under conditions of zero compensation. Bankers were asked for their views on any potential "penalty spread" which might apply to all three types of power project technologies in Australia. Our reasoning here was twofold. Conflicting signals from political parties results in risk being priced, and bad debts represent business costs which must be recovered by firms to remain profitable; this includes banks. The results from the second segment of our survey are illustrated in Table 5.

Table 5: Survey results on PF "penalty spreads"

\begin{tabular}{lr}
\hline Technology & bp premium \\
\hline Existing coal & $150-200$ \\
New gas & $100-150$ \\
New renewable & $50-100$ \\
\hline
\end{tabular}

Source: AGL Energy Ltd.

This survey data from Australia's top utilities project bankers provides us with unique insights around the extent of potential economic efficiency losses that might accumulate in the electricity

${ }^{11}$ Estimates on the costs associated with this policy uncertainty can be found in Nelson et al (2010). 
sector if a brown coal power station defaulted on debt facilities under conditions of zero compensation. Clearly, expanding credit spreads will increase the underlying cost of power generation through higher interest costs, shortened tenors and consequent lower gearing levels.

Policy makers may well be indifferent about wealth transfers between incumbent brown coal equity holders and debt holders. But any policymaker would be rattled by the $2^{\text {nd }}$ line result in Table 5 relating to new gas plant (+150bps), and policy advisors to the Greens will no doubt be stunned by the $3^{\text {rd }}$ line result relating to new renewables (+100bps); and given their opposition to structural adjustment assistance to coal generators, they should be. Even though penalty spreads in Table 5 clearly decline with the emissions intensity of the technologies, renewables are the most capital-intensive power generating technology with low capacity factors and are therefore hyper-sensitive to changes in the cost of capital. In the event, new renewables experience the most profound 'hit' to generalized long run marginal cost estimates, and as modeling results in the next section reveal, they are non-trivial in every respect. In short, policy uncertainty and zero compensation actually does much more damage to the entry prospects of new renewable plant than it does to existing coal plant or new gas plant.

To make matters worse, if the new entrant cost of gas and renewable plant is adversely affected, it does not just affect the economics of singular new entrant plant. Even though only a handful of plants may be directly affected by this change, the nature of energy markets means that clearing prices must rise to the cost of entry, and so if an outcome of zero compensation is a "penalty spread' being added to the underlying cost of capital and gearing levels reduce, then this will increase wholesale electricity prices, and in turn, retail electricity prices across the entire 8.9 million households in the NEM; a sobering thought for policymakers of all persuasions.

It stands to reason that margins on all new plant would be elevated if a brown coal plant collapses due to zero compensation; we considered this to be entirely predictable and survey results merely confirm this. Gas and renewable plant are being developed in response to (appropriate) government policy settings. But if government policy disrupts historic investments, policy risk will be priced into the generation sector until such risk is perceived to have diminished to trivial levels. In Australia, the Government and the Opposition currently support a 5\% carbon target, but the Greens (who hold the voting balance of power in the Australian Senate) do not. And while the Government and Greens support a price on carbon, the Opposition does not. And the fact that the Opposition has stated it will repeal government carbon pricing plans will not help to diminish policy risk perceptions in Australia.

\section{Scenarios and project finance modeling results}

To see how changes in parameters affect the underlying cost structures of benchmark base load CCGT plant, peaking OCGT plant and renewable plant in the NEM, we have made use of the Project Finance Model (PF Model) from Simshauser (2009) and applied current market conditions from observed capital market data and the survey results from Tables 3 and 5 to quantify economic efficiency losses.

The PF Model is a dynamic, multi-period cash flow simulation model of a power project in which all the parameters of a given plant and required project finance are incorporated to determine unit costs, debt sizing and structuring. The model calculates annual energy production, revenues, fixed and variable operations and maintenance costs, fuel costs, capital works, taxation schedules and establishes project finance bullet and semi-permanent amortising term facilities.

Refinancings are undertaken while all structured debt facilities are extinguished within a 25-year aggregate tenor. Under ideal conditions, two debt facilities are assumed; a 7-year interest-only 'bullet' and a 12-year semi-permanent amortising facility, with relevant interest rate swaps matching the tenors. In the PF Model, we set the forward curve for base load power to the LRMC of the plant in question which allows us to put the optimal capital structure in place thus 
minimizing the overall unit cost of the plant, albeit within the constraints of debt sizing, viz. via Debt Service Cover Ratio (DSCR) and Loan Life Cover Ratio (LLCR). ${ }^{12}$ The model specifications have been documented extensively in Simshauser (2009) and therefore we do not propose to reproduce them here.

For the purposes of our analysis, we have modeled three distinct scenarios:

1. Certainty Scenario: Key assumptions in this scenario are that carbon pricing is implemented, structural adjustment assistance is well designed, bipartisan support is achieved and so perceptions over policy uncertainty are diminished to trivial levels (for example, as in the EU). Spreads on PF facilities therefore reduce to levels in-line with reductions in the debt capital markets and global power PF markets. ${ }^{13}$ In our Certainty Scenario, we assume power $\mathrm{PF}$ spreads reduce by $33 \%$ and narrow in range, from $350-400 \mathrm{bps}$ to $250-275 \mathrm{bps}$. We assume 12 year tenors in line with global data, and gearing levels of $67.5 \%$ in-line with historic conditions.

2. Uncertainty Scenario: Primary assumptions in the uncertainty scenario are that welldesigned structural adjustment assistance forms a central part of carbon policy but unresolved policy conflicts remain between the Government, the Opposition and Greens on the mechanism and targets respectively. Margins for new plant reflect those from our Table 3 results at 350-400bps, 7-year tenors and gearing of $60 \%$.

3. Meltdown Scenario: Key assumptions in this scenario are that zero compensation applies, that coal generators experience financial distress, and policy conflicts remain between political parties, representing the worst of all worlds with spread premiums applying at the rates outlined in Table 5 and gearing reverting to $55 \%$.

Table 6 sets out the assumptions that apply for a 1 x 400MW CCGT project, a 3 x $175 \mathrm{MW}$ OCGT project and a 200MW wind project in 2011, with changes to spreads, tenors and gearing as outlined above.

Table 6: PF assumptions for power plant banked in 2011

\begin{tabular}{|c|c|c|c|c|c|c|c|}
\hline Inflation & & & & & Taxation & & \\
\hline$-\mathrm{CPI}$ & $(\%)$ & $2.50 \%$ & & & - Tax rate & $(\%)$ & 30.00 \\
\hline - Elec Price Inflation & $(\%)$ & 2.13 & & & - Useful life & (Yrs) & 30 \\
\hline Plant Costs \& Prices & & CCGT & OCGT & Wind & Debt Sizing Parameters & & \\
\hline - Plant size & (MW) & 400 & 525 & 200 & - DSCR & (times) & 1.8 to 2.2 \\
\hline - Capital cost & $(\$ / \mathrm{kW})$ & 1,500 & 980 & 2,500 & - LLCR & (times) & 1.8 to 2.2 \\
\hline - Acquisition price & $(\$ M)$ & 600 & 515 & 500 & - Gearing & $(\%)$ & 55 to 67.5 \\
\hline LRMC Statistics & & & & & - Lockup & (times) & 1.35 \\
\hline - LRMC in $2011 \$$ & $(\$ / M W h)$ & 76.14 & 14.22 & 120.39 & - Default & (times) & 1.10 \\
\hline - Heat rate & $(\mathrm{kJ} / \mathrm{kWh})$ & 7,000 & 11,400 & - & & & \\
\hline - Unit fuel & $(\$ / G J)$ & 4.50 & 6.00 & - & Facilities & Swap & Spread bps \\
\hline - Variable O\&M & $(\$ / \mathrm{MWh})$ & 3.00 & 8.00 & 1.00 & -5 year tenor & $5.76 \%$ & $250-525$ \\
\hline - O\&M costs & (\$M pa) & 12.4 & 6.8 & 8.6 & -7 year tenor & $5.94 \%$ & $275-550$ \\
\hline - Capex & (\$M pa) & 3.0 & 0.2 & 0.5 & -12 year tenor & $6.11 \%$ & $275-550$ \\
\hline - $\mathrm{CO} 2$ footprint & $(\mathrm{t} / \mathrm{MWh})$ & 0.39 & 0.59 & - & - Refinancings & $6.11 \%$ & $250-375$ \\
\hline - Remnant life & (Yrs) & 40 & 30 & 30 & - Post Tax Equity & & $15 \%$ \\
\hline
\end{tabular}

PF Model results for CCGT plant under the three scenarios are illustrated in Figure 6. Primary debt covenants are within tolerance with DSCR at 2.0 times and the LLCR at 1.8 times in the certainty (i.e. benchmark) scenario. The bar chart illustrates headline LRMC including carbon at

\footnotetext{
${ }^{12}$ In a project finance, three parameters typically limit the size of the facilities; (1) absolute project gearing, (2) Debt Service Cover Ratio (DSCR) at 1.8-2.2 times; and (3) Loan Life Cover Ratio (LLCR) at 1.8-2.2 times the present value of future cash flows.

${ }^{13}$ Recall from Table 3 that spreads for corporate bonds have reduced by $33 \%$ to $240 \mathrm{bps}$ since 2008, and global PF facilities now average about $240 \mathrm{bps}$ over swap.
} 
$\$ 30 /$ t. The range in headline LRMC spans $\$ 3.70 / \mathrm{MWh}$, from $\$ 74.13$ to $\$ 77.83 / \mathrm{MWh}$. A shift of roughly $\$ 4 / \mathrm{MWh}$ may not appear significant, but given NEM demand of about 200 million MWh per annum, it will result in cost inefficiencies of about $\$ 800$ million pa.

Figure 6: PF Model results for CCGT under certainty, uncertainty and meltdown conditions

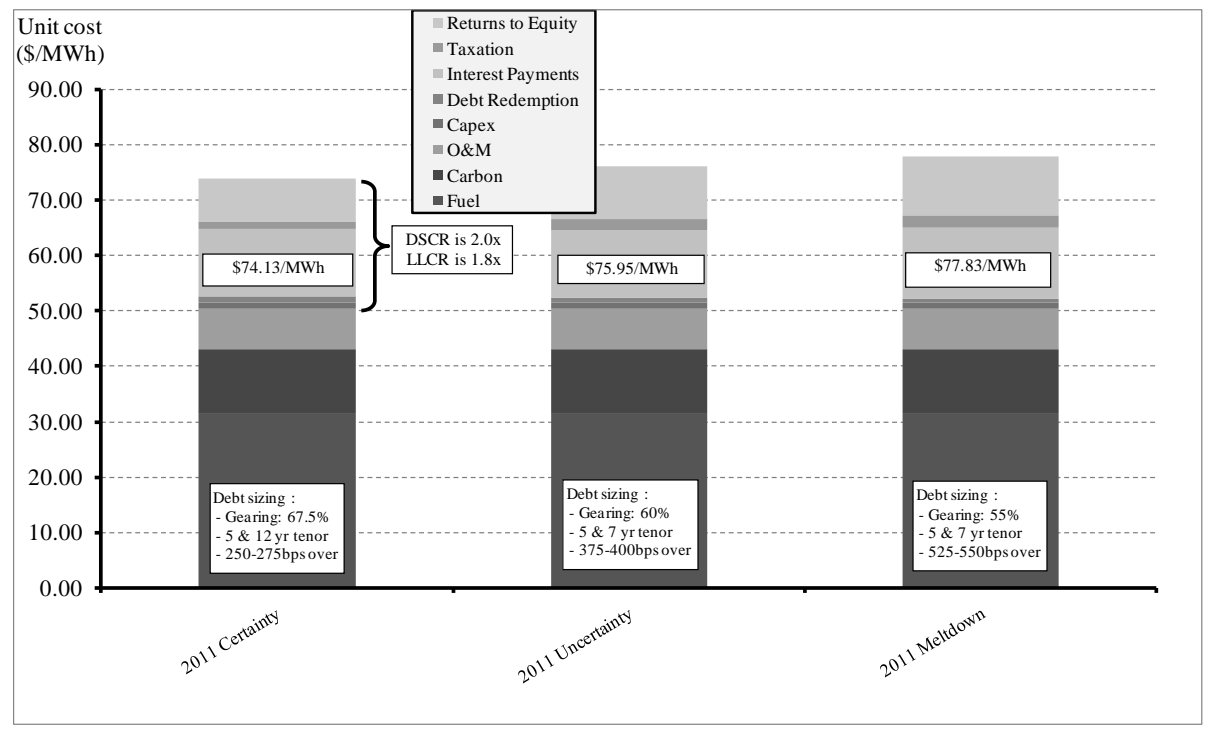

Next, we analysed the economic inefficiency that would apply to the fleet of peaking OCGT plants, which is illustrated in Figure 7. We measure peaking plant by their 'carrying cost' or 'fixed costs' including profit recovery. This can be thought of as the fair value for call options (in $\$ / \mathrm{MW} / \mathrm{h}$ ) written by new entrant peaking plant with a $\$ 300 / \mathrm{MWh}$ strike price. The marginal running cost of such plant, regardless of fixed costs, is about $\$ 94 / \mathrm{MWh}$ including carbon at $\$ 30 / \mathrm{t}$. The PF Model produces carrying costs ranging from $\$ 13.09 / \mathrm{MW} / \mathrm{h}$ to $\$ 15.29 \mathrm{MW} / \mathrm{h}$ under the three scenarios. This $\$ 2.20 / \mathrm{MW} / \mathrm{h}$ differential is also significant because the NEM will carry about $11,000 \mathrm{MW}$ of peaking plant by 2015 . Accordingly, potential economic inefficiencies arising from our meltdown scenario amount to $\$ 212$ million pa by comparison to the certainty scenario.

Figure 7: PF Model results for OCGT under certainty, uncertainty and meltdown conditions

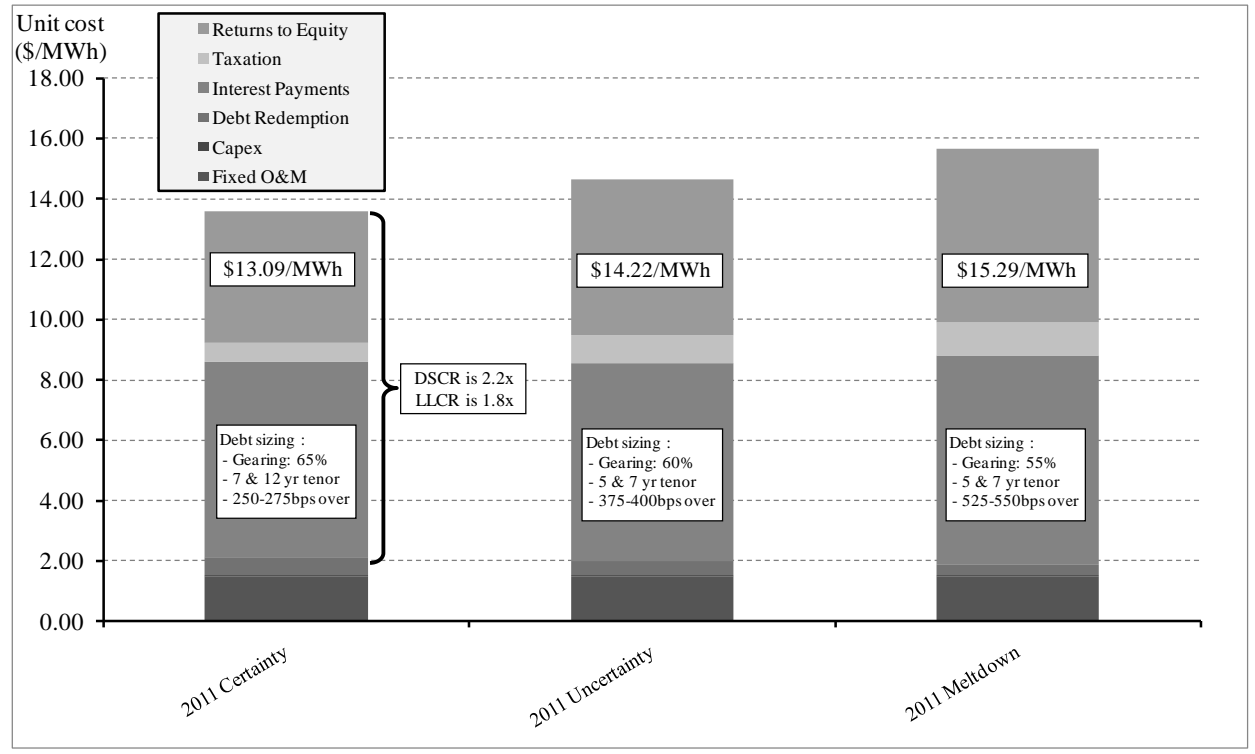


Our PF Model results for renewable plant (i.e. wind) are illustrated in Figure 8. In modeling wind projects, we applied substantially higher gearing levels than Table 6 indicates, and this is appropriate. The certainty scenario is geared at $76 \%$ with differential gearing equivalent to our thermal plant modeling. Debt sizing parameters were also different. Whereas thermal plant typically faces DSCR's of 1.8-2.2 for debt sizing, the capital intensive nature of wind means that the ratios are relaxed, in this instance to 1.35-1.45 times. Our sizing ended up with a DSCR of 1.42 times, well within the acceptable envelope.

Figure 8: PF Model results for wind under certainty, uncertainty and meltdown conditions

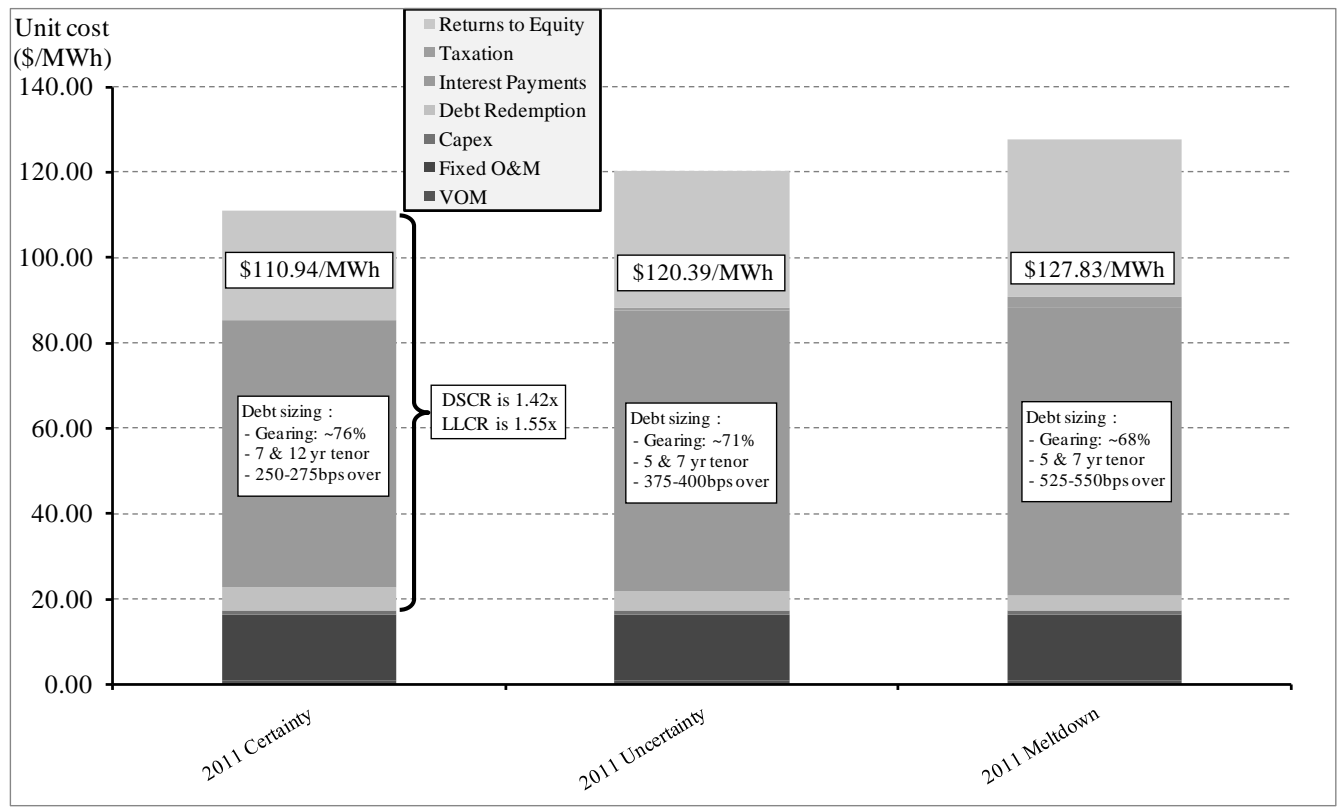

Note that the LRMC of wind in the certainty scenario is $\$ 110.94 / \mathrm{MWh}$. The LRMC of wind in the meltdown scenario is $\$ 127.83 / \mathrm{MWh}$ and so the difference in the cost of wind plant between the certainty and meltdown scenario is a surprisingly large $\$ 16.89 / \mathrm{MWh}$, three times higher than the cost impact on CCGT plant due to the capital intensive nature of rewnewables. The 2015 Renewable Policy target is about $18,000 \mathrm{GWh}$, and so economic efficiency losses arising from the meltdown scenario would total $\$ 232$ million pa.

\section{Partial equilibrium modeling results}

Higher LRMC for new gas and renewable plant have obvious and non-trivial impacts on forward electricity prices. As the NEM operates under a uniform, first-price, energy-only gross pool auction design, the value of spot and forward prices must ultimately rise to the cost of entry prior to new plant being built. To assess the economic impact of our different scenarios on electricity prices, we assume financing costs calculated in previous sections begin to bind immediately, but are revealed in the market from 2015 onwards as new plant is commissioned. CCGT forms the dominant base and intermediate load technology while OCGT undertake peaking duties. Individual plant costs under the certainty, uncertainty and meltdown scenarios are then applied between 2015 and 2020, which by implication represents investment origination commitments over the period between 2013 and 2017. We consider any elevation in margins must ultimately be exhausted as regulatory risk perceptions return to normal; hence our limited five-year period of analysis.

We utilise the Optimal Plant Mix Model (OPM Model) from Simshauser and Wild (2009) to undertake the analysis. This partial equilibrium electricity system model simulates half-hour resolution and assumes perfect competition and essentially free entry to install any combination 
of capacity that satisfies differentiable conditions. The lumpiness of capacity is a constraint; firms may chose either 400MW CCGT base load plant or clusters of OCGT plant with unit sizes of $175 \mathrm{MW}$, the latter based on conventional 'E Frame' gas turbine technology. As this model has been thoroughly documented in Simshauser and Wild (2009), we do not intend to reproduce it here. A graphical representation of the half-hourly modeling results is presented in Figure 9.

Figure 9: 2015 Load Duration Curve and Implied Optimal Plant Mix

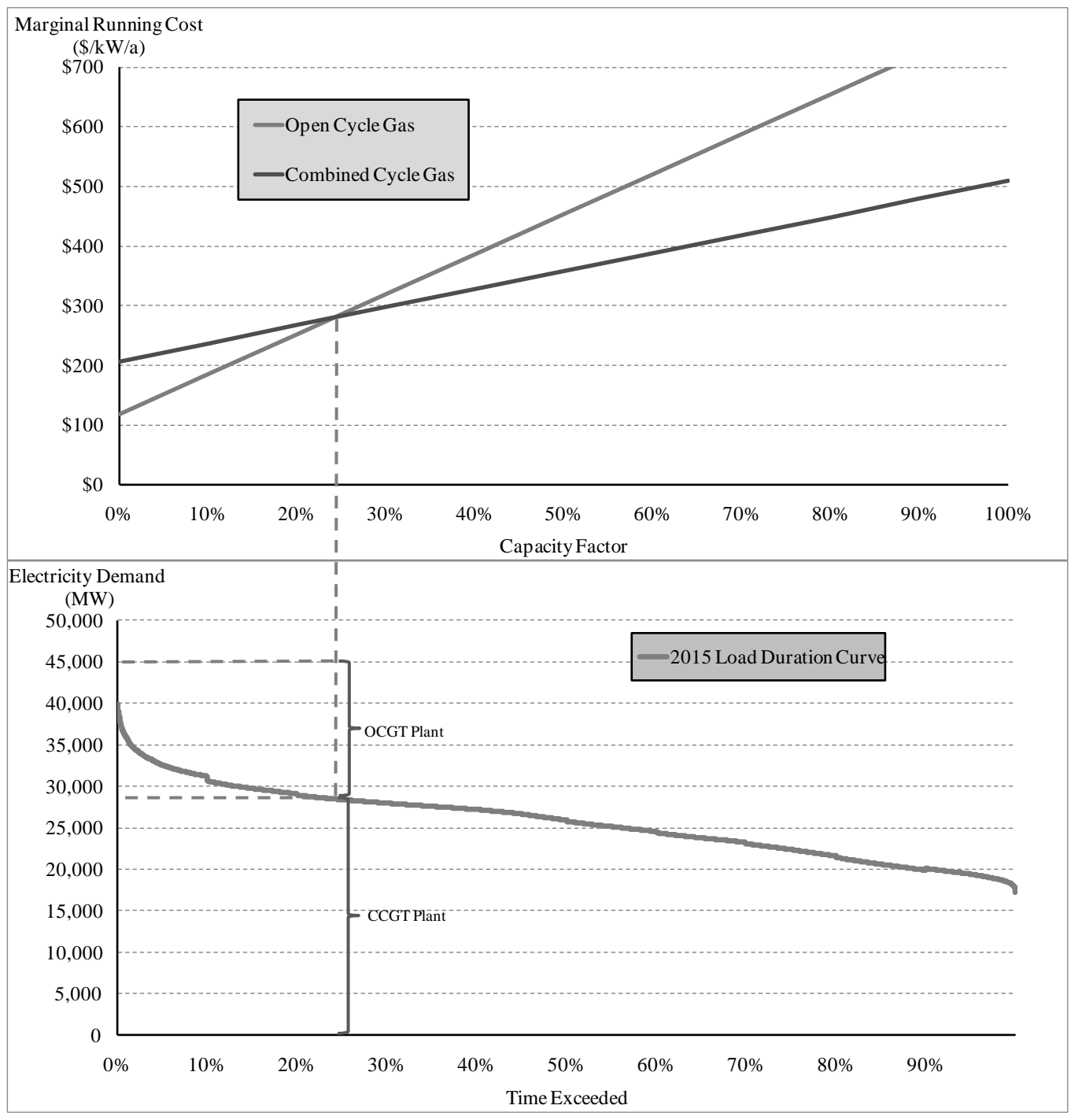

The top graph in Figure 9 is a transformation of PF Model results for CCGT and OCGT plant into marginal running cost curves. The y-axis intercepts represent annual fixed costs of the plant, and the slope of the curves represent marginal running costs (i.e. fuel and variable O\&M). The crossover point, at about $25 \%$, identifies the annual capacity factor at which all gains from investing in low capital cost OCGT plant are exhausted by the higher capital but more operationally efficient CCGT plant.

The bottom graph in Figure 9 presents the 17520 half-hourly electricity load points for 2015 . This equilibrium-demand data has been plotted in descending order to form a load duration curve. In establishing our load curve for the NEM, we have aggregated historical State-based loads. Utilising the methodology in Nelson et al. (2010), load duration curves were developed for the years 2015 to 2020, with the OPM Model used to calculate supply-side investment optimality in each of our three scenarios. We assume average annual growth for each decile of the load 
duration curve at the historic 10-year moving average, and apply this to predict demand for each half hour of the curve in the years between 2015 and 2020. This translates into energy growth rates of about $1.5 \%$ per annum, with increases occurring primarily during peak and high demand periods. Our approach to quantifying the costs of uncertainty is identical to that in Nelson et al. (2010) in that our analysis is largely quarantined to the period between 2015 and 2020. System average cost for each scenario is presented in Table 7.

Table 7: NEM system average cost between 2015 and 2020 (2011\$)

\begin{tabular}{cccc}
\hline & $\begin{array}{c}\text { Certainty } \\
\$ / \mathrm{MWh}\end{array}$ & $\begin{array}{c}\text { Uncertainty } \\
\$ / \mathrm{MWh}\end{array}$ & $\begin{array}{c}\text { Meltdown } \\
\$ / \mathrm{MWh}\end{array}$ \\
\hline $\begin{array}{c}\text { Headline energy cost } \\
\text { (including } \mathrm{CO}_{2} \text { ) }\end{array}$ & 82.54 & 85.00 & 87.07 \\
\hline
\end{tabular}

There is a material difference in NEM-wide system average cost between scenarios. Headline average costs in the uncertainty and meltdown scenarios are \$2.46/MWh and \$4.54/MWh higher than our benchmark certainty scenario, representing increases of between $2.46 \%$ and $4.54 \%$ respectively. Importantly, the Table 7 results exclude renewable plant impacts; Section 5 noted these were surprisingly large in the meltdown scenario. When combined, it is clear that there are material consequences for electricity prices associated with implementing a Washington Consensus approach to carbon policy. ${ }^{14}$ System aggregate economic efficiency losses across the 2015-2020 period are illustrated in Figure 10.

Figure 10: Efficiency losses in the NEM between 2015 and 2020 (2011\$)

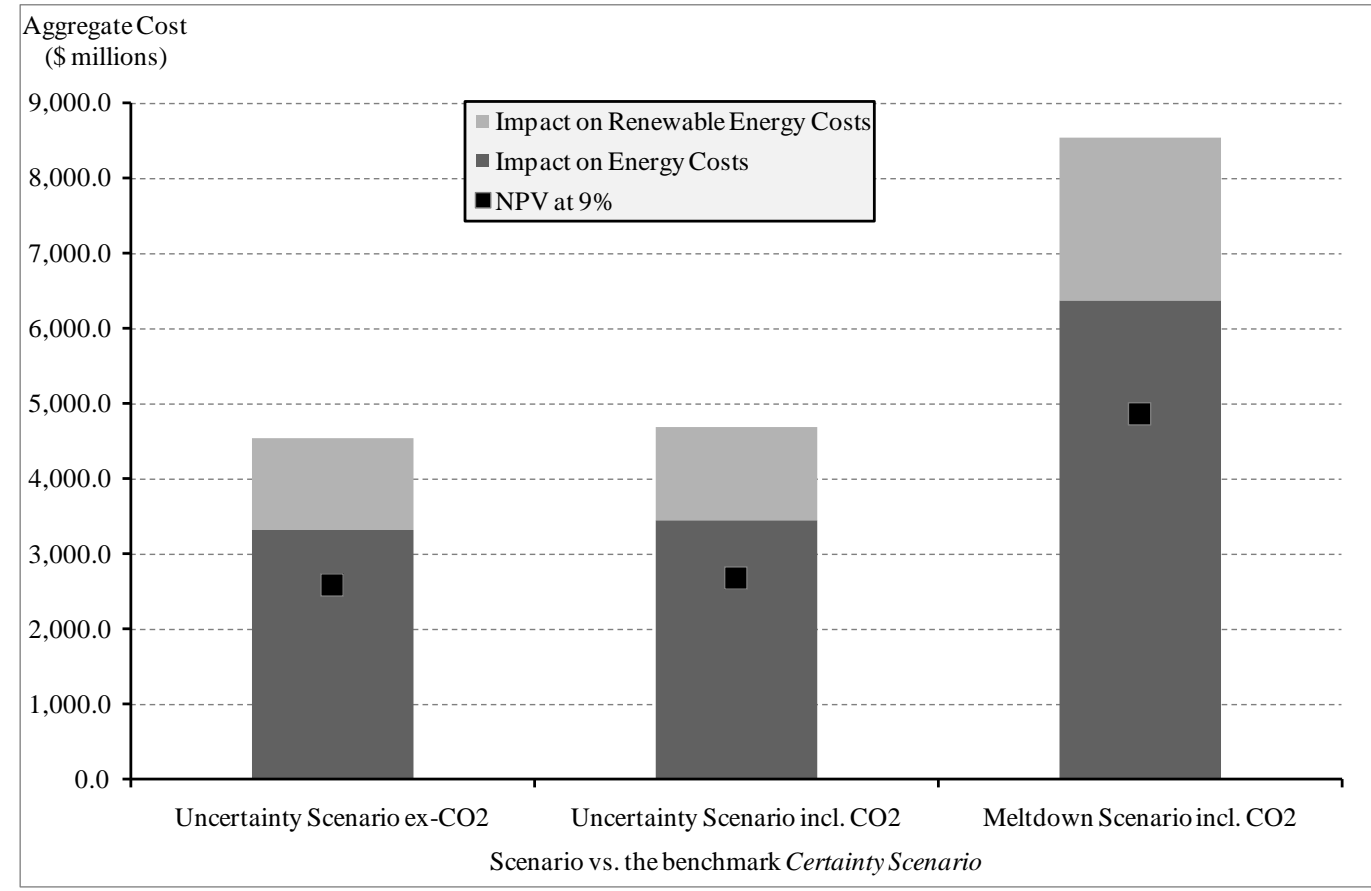

The first two bar results in Figure 10 illustrate the aggregate power system cost impact of ongoing policy uncertainty between the Government, Opposition and the Greens and amounts to $\$ 4.5$ billion without $\mathrm{CO}_{2}$ pricing, and $\$ 4.7$ billion with $\mathrm{CO}_{2}$ pricing. The reason for the trivial difference between these two scenarios should be obvious enough; unless the Government provides a framework for a formal carbon price, a shadow carbon price fills the void in any event. In short, both the energy and finance industries view a carbon price as inevitable whether one exists or not, and thus all of the uncertainty remains. Our partial equilibrium modeling results for

${ }^{14}$ These impacts also need to be considered against a background of electricity prices doubling between FY08 and FY15, being driven by network capital investments (Simshauser et al., 2011). 
the meltdown scenario (including $\mathrm{CO}_{2}$ ) puts aggregate economic efficiency losses of $\$ 8.5$ billion, the details of which are summarized as follows:

- Power system economic efficiency losses in 2015 total $\$ 1.25$ billion (i.e. $\$ 1021 \mathrm{~m}$ in headline energy costs and $\$ 231 \mathrm{~m}$ from renewable energy);

- Power system economic efficiency losses in 2020 total $\$ 1.63$ billion (i.e. $\$ 1102 \mathrm{~m}$ in headline energy costs and $\$ 527 \mathrm{~m}$ from renewable energy);

- Aggregate power system efficiency losses between 2015-2020 amounts to $\$ 8.6$ billion (i.e. $\$ 6.4 \mathrm{~b}$ in headline energy costs and $\$ 2.2 \mathrm{~b}$ in additional renewable energy costs); and

- The Present Value of economic efficiency losses over the 2015-2020 period at a 9\% private sector real discount rate amounts to $\$ 4.9$ billion (with economic efficiency losses assumed to be zero until 2015).

\section{Policy recommendations and concluding remarks}

It is clear that climate change reforms without adequate structural adjustment assistance run a high risk of a material misallocation of resources in a sector that provides a universally acknowledged essential service. We noted that this is one trigger to justify the use of structural adjustment assistance. We also noted that where a reform results in economic shocks that are large; driven by policy changes; involving a breach of long standing expectations and result in highly uneven or magnified losses in discrete industrial segments are another trigger. All of these conditions are satisfied. Modeling completed for the Australian Government in 2008 demonstrated that the impact on brown coal-fired generators is likely to be in the order of $\$ 7.9$ billion. Our contribution to understanding the impacts has been to highlight economic efficiency losses that might arise under a Washington Consensus counterfactual scenario of zero compensation. Our modeling results provide an important message - there is a sound public policy case for providing structural adjustment assistance to intensely affected coal generators. Our modeling results (in 2011\$) concluded economic efficiency losses of $\$ 1.63$ billion pa in 2020 and $\$ 8.5$ billion in aggregate over the period 2015-2020. Such an outcome is clearly undesirable from a welfare perspective and from an electricity consumer's viewpoint. The implications from this analysis are clear. Policy certainty and structural adjustment assistance are critical and requisite elements in relation to carbon policy.

While we have quantified costs of zero compensation, we have not quantified what level of structural adjustment assistance is necessary to avoid such outcomes. That is an entirely separate exercise for energy and financial economists. And as we noted at the outset, economists can provide advice, but the ultimate decision is a matter of judgment for policymakers.

The costs of our counterfactual zero compensation scenario are substantial, and so policymakers must turn their attention to how structural adjustment assistance should be provided. We believe that an administrative allocation of permits as was prescribed in the EU has a distinct advantage over other options because it 'self-corrects' where anticipated abatement costs do not materialize. If the value of the permits falls, so too does the need to provide structural adjustment assistance. This concept is analogous to the 'automatic stabiliser' notion of taxation and transfer payments in a fiscal policy context. The EU policy may have led to windfall profits, but only because of an overzealous allocation, not because the policy was somehow fundamentally flawed. Importantly, any future application needs to ensure that generators receiving assistance can close plant at any time subject to maintaining capacity (but not necessarily output) for system security purposes, and provisions to claw-back any so-called windfall gains would be entirely appropriate.

In a public policy design, it is necessary to be clear about the objectives being pursued. The provision of structural adjustment assistance to greenhouse intensive coal-fired generator should have a short-run objective function of ensuring energy security and avoiding systemic shocks to energy markets, and a long-run objective of avoiding economic efficiency losses from emerging 
in capital markets, and in turn, minimizing electricity price impacts on consumers. In any environment where the probability of an event occurring is significant, and the consequence extreme, it is prudent to take action to prevent the event from taking place. This precautionary principle guides policymakers in all aspects of economic management, and given electricity is an essential service, carbon policy design should be no different.

\section{References}

ACIL Tasman (2011), Energy security and the introduction of GHG emissions pricing, ACIL Tasman Publications, Melbourne

ACIL Tasman (2008), Impacts of the Carbon Pollution Reduction Scheme and RET - Modeling of impacts on generator profitability, ACIL Tasman Publications, Melbourne

Argy, F. (1999), "Distribution effects of structural change: some policy implications", in Structural adjustment - exploring the policy issues, Productivity Commission, Canberra: AusInfo, pp 39-92.

Bushnell, J. (2004), “California's electricity crisis: a market apart?”, Energy Policy, 32(9): 1045-1052.

DCC: Department of Climate Change (2009), Proposed Package of Measures to Safeguard the Security of Australia's Electricity Supplies. Commonwealth Government, Canberra

Energy Supply Association of Australia (2010), Electricity Gas Australia, ESAA Publication, Melbourne.

Garnaut: Garnaut Climate Change Review Update, (2011), Transforming the electricity sector - update paper 8, Commonwealth Government, Canberra.

Johnson, O. (1994), "Managing adjustment costs, political authority and implementation of adjustment programs with special reference to African countries", World Development, 22:3(399-411).

Joskow, P. (2001), “California's electricity crisis”, Oxford Review of Economic Policy, 17(3): 365-389.

Neary, P, (1982), "International capital mobility, wage stickiness and the case for adjustment assistance" in J. Bhagwati (Ed.), Import Competition and Response, University of Chicago Press, Chicago, pp. 39-67.

Nelson, T., Kelley, S., Orton, F. and Simshauser, P. (2010), "Delayed carbon policy certainty and electricity prices in Australia", Economic Papers, 29(4): 1-20.

Nelson, T., Kelley, S. and Orton, F. (2011), "The impact of carbon pricing on Australian deregulated wholesale electricity and gas markets", AGL Working Paper No.23, AGL Publication, Sydney. Available at www.aglblog.com.au

Pasour, E. (1973), "Economic growth and agriculture: an evaluation of the compensation principle", Amercian Journal of Agricultural Economics, 55(4): 611-616.

Macquarie Securities, (2011), "The visible hand: the IMF leopard changes is spots", Macquarie Economic Research Publication, 8 April 2011, Sydney.

McLennan Magasanik Associates (2008), "Impacts of the Carbon Pollution Reduction Scheme on Generator Profitability", MMA Publication, Melbourne.

Outhred, H. (2011), Stateline, ABC TV (http://www.abc.net.au/news/video/2011/02/11/3136902.htm accessed on 30 March 2011), Sydney

ROAM (2008), "Modeling of carbon pricing scenarios", ROAM Consulting Publication, Brisbane.

Samuelson, R. (2009), "Economists ignored history”, Australian Financial Review, 6 July 2009, p.55. 
Satkunasingam, V. (2011), “Australia's power landscape”, Project Finance International, Issue 453, pp.

Simshauser, P. (2005), "The gains from the microeconomic reform of the power generation industry in east coast Australia", Economic Analysis and Policy, 35(1\&2): 23-43.

Simshauser, P. (2008), "On Emission Permit Auction vs. Allocation and the Structural Adjustment of Incumbent Power Generators in Australia", The Electricity Journal, 21(10): 30-41.

Simshauser, P. (2009), "On emissions trading, toxic debt and the Australian power market", The Electricity Journal, 22(2): 9-29.

Simshauser, (2010), "Resource adequacy, capital adequacy and investment uncertainty in the Australian power market", The Electricity Journal, 23(1): 67-84.

Simshauser, P. (2011), "The hidden cost of wind generation in a thermal power system: what cost?", Australian Economic Review, 44(2): article in-press.

Simshauser, P. and Doan, T. (2009), "Emissions Trading, Wealth Transfers and the Wounded Bull Scenario in Power Generation", Australian Economic Review, 42(1): 64-83.

Simshauser, P., Nelson, T. and Doan, T., (2011) "The Boomerang Paradox Part 1: how a nation's wealth is creating fuel poverty", The Electricity Journal, 24(1): 72-91.

Simshauser, P. and Wild, P. (2009), "The Western Australian Power Dilemma", Australian Economic

Papers, Vol. 48, No.4, pp 342-369.

Stiglitz, J. (2002), Globalisation and its discontents, Norton \& Co, New York. 